\title{
Jururumberus, a new genus of Orthocladiinae (Diptera: Chironomidae) from Brazil
}

\author{
Humberto Fonseca Mendes ${ }^{1,3}$ \& Trond Andersen ${ }^{2}$ \\ ${ }^{1}$ Centro de Ciências Naturais e Humanas - CCNH,Universidade Federal do ABC - UFABC, \\ Bl. A, 638-3, Rua Santa Adélia 166, Bangu,CEP 09210-170, Santo André, SP, Brazil \\ ${ }^{2}$ Department of Natural History, University Museum of Bergen, University of Bergen, \\ CP 7800, N-5020 Bergen, Norway \\ ${ }^{3}$ Corresponding author: Humberto Fonseca Mendes, e-mail: orthocladiinae@gmail.com
}

MENDES, H.F., \& ANDERSEN, T. Jururumberus, a new genus of Orthocladiinae (Diptera: Chironomidae) from Brazil. 13(4): http://www.biotaneotropica.org.br/v13n4/en/abstract?article+bn01213042013

Abstract: Jururumberus n. gen. is erected based on the males of J. arapuca n. sp. from São Paulo State, in southeastern Brazil and J. uatuma n. sp. from the Amazonas in northern Brazil. The genus can be separated from other Orthocladiinae based on the combination of bare eyes, wing, and squama; frons U-shaped, extended ventrally; $A R \leq 0.3$, antenna without apical seta; palp short, five-segmented, with sensilla clavata in subapical sensillum coeloconicum; no acrostichals; costa strongly extended; $\mathrm{R}_{4+5}$ ending proximal to $\mathrm{M}_{3+4}$; anal point narrowly triangular with microtrichia only, sitting high on tergite IX; and virga composed of two spines.

Keywords: Chironomidae, Orthocladiinae, Jururumberus, new genus, new species, Brazil, Neotropical region, Mata Atlântica, Amazon.

MENDES, H.F. \& ANDERSEN, T. Jururumberus, um gênero novo de Orthocladiinae (Diptera: Chironomidae) do Brasil. 13(4): http://www.biotaneotropica.org.br/v13n4/pt/abstract?article+bn01213042013

Resumo: Jururumberus n. gen. é descrito baseado em machos de J. arapuca n. sp. do Estado de São Paulo, no sudeste brasileiro e J. uatuma n. sp. do Estado do Amazonas no norte brasileiro. O gênero pode ser separado dos demais Orthocladiinae com base na combinação dos seguintes caracteres: olhos, asas e squama nus; fronte em forma de ' $U$ ', extendido ventralmente; $\mathrm{AR} \leq 0.3$, antena sem seta apical; palpo encurtado, com cinco segmentos, com sensilas clavadas em uma sensila celocônica subapical; acrosticais ausentes; veia costal fortemente extendida; $\mathrm{R}_{4+5}$ terminando proximal em relação a $\mathrm{M}_{3+4}$; ponta anal estreita e triangular com apenas microtríquios, situada oralmente no tergito IX; virga composta de dois espinhos.

Palavras-chave: Chironomidae, Orthocladiinae, Jururumberus, gênero novo, espécie nova, Brasil, região Neotropical, Mata Atlântica, Amazônia. 


\section{Introduction}

In their catalog of the Neotropical and Mexican chironomids Spies \& Reiss (1996) recorded seven Orthocladiinae species from Brazil; one of these, Ichthyocladius neotropicus Fittkau, as uncertain, a species which later has proved not to occur in Brazil (Mendes et al. 2004). Ten years later Mendes et al. (2007) listed 37 species of orthoclads, while today about 100 species are known to occur in Brazil (Mendes \& Pinho 2011). Several genera are so far only recorded from Brazil, viz. Gynocladius Mendes, Sæther et Andrade-Morraye, Iporangomberus Mendes et Andersen, Lyrocladius Mendes et Andersen, Miambera Andersen et Mendes, Maximberus Andersen et Mendes, Oleia Andersen et Mendes, Saetherocladius Andersen et Mendes, Saetherocryptus Andersen et Mendes, Saetherolabis Andersen et Mendes, Saetherops Andersen et Mendes, and Ubatubaneura Wiedenbrug et Trivinho-Strixino, but a wider distribution of several of these genera is to be expected.

However, a high number of new species still await description. When collecting in Brazil many of the orthoclads encountered do not readily fit into any described genus. Several of these might be terrestrial or semi-terrestrial and the larvae and pupae might be difficult to locate. Below we describe the males of two of these species and place them in a new genus. One of these species was taken in Boracéia Biological Reserve in São Paulo State in the coastal rainforest Mata Atlântica. The other species was collected in Uatumã Biological Reserve in the Amazonas State, in the Amazonian rainforest. Both species were collected in light traps.

\section{Material and Methods}

The specimens were mounted in Canada Balsam or Euparal following the procedures outlined by Sæther (1969). The general morphology follows Sæther (1980). Measurements are given as ranges.

The types will be deposited in Museu de Zoologia da Universidade de São Paulo (MZUSP) and in the Department of Natural History, University Museum of Bergen, University of Bergen, Bergen, Norway (ZMBN).

\section{Jururumberus new genus}

Type species: Jururumberus arapuca $\mathrm{n}$. sp.

Other included species: Jururumberus uatuma $\mathrm{n}$. sp.

Etymology: Deriving from the South American native language Tupi yuru-ru and mberui, meaning melancholic, sad and midge, mosquito, respectively, due to their gloomy facial expression. Gender of the genus name: masculine.

Diagnostic characters: The combination of bare eyes, wing, and squama; frons $U$-shaped, extended ventrally; $A R \leq 0.3$, antenna without apical seta; palp short, five-segmented, with sensilla clavata in subapical sensillum coeloconicum; no acrostichals; costa strongly extended; $\mathrm{R}_{4+5}$ ending proximal to $\mathrm{M}_{3+4}$; anal point narrowly triangular with microtrichia only, sitting high on tergite IX; and virga composed of two spines will separate the genus from all other orthoclads.

\subsection{Description}

Small sized species, wing length 0.67-0.87 mm.

Head. Eyes bare, reniform, without dorsomedian extension. Antenna with 12 flagellomeres, AR $\leq 0.30$; sparsely plumed; groove beginning on segment 1 ; sensilla chaetica present on flagellomeres 1-3 and ultimate; without subapical seta. Palp five-segmented, short; third palpomere with 5-7 sensilla clavata in subapical sensillum coeloconicum. Temporal setae in single row, all comparatively long. Frons U-shaped, extended ventrally; frontal tubercle absent.
Tentorium and stipes normal. Cibarial pump with anterior margin weakly convex. Clypeus with few setae.

Thorax. Antepronotal lobes widely separated medially, with few, weak lateral antepronotals. Acrostichals absent; dorsocentrals few, uniserial; prealars few; supraalar absent. Scutellum with few setae in single row.

Wing. Membrane without setae, with fine punctuation. Anal lobe weakly developed. Costa strongly extended; $\mathrm{R}_{2+3}$ running and ending midway between $\mathrm{R}_{1}$ and $\mathrm{R}_{4+5} ; \mathrm{R}_{4+5}$ ending proximal to $\mathrm{M}_{3+4} ; \mathrm{FCu}$ distal to $\mathrm{RM} ; \mathrm{Cu}_{1}$ slightly curved. Brachiolum with 1 seta, other veins bare. Squama bare. Sensilla campaniformia about 6 apically, 5 basally, and 2 above seta on brachiolum; 1 on RM; and 1 basally on $\mathrm{R}_{1}$.

Leg. Tibial spurs normal, comb of hind tibia composed of 9-12 setae. Tarsal pseudospurs and sensilla chaetica absent. Pulvilli vestigial.

Abdomen. Abdominal setation reduced. Tergite I bare, tergites II-III bare or with two irregular rows of few setae, tergites IV-VIII with two irregular rows of few setae. Sternites I-II bare, sternites IIIV bare or with single median setae, sternites V-VIII with single or few setae medially in two irregular rows.

Hypopygium. Anal point narrowly triangular, sitting high on tergite IX, with microtrichia only. Tergite IX with few long setae; laterosternite IX with few setae. Apodemes well sclerotized. Phallapodeme with normal aedeagal lobe. Transverse sternapodeme straight to weakly arched, oral projections distinct. Virga consisting of 2 separate spines. Gonocoxite with well developed inferior volsella, with posterior, free lobe. Gonostylus club-shaped, covered with microtrichia and with few, weak setae; crista dorsalis present; megaseta normal.

Female, pupa and larva. Unknown.

\subsection{Systematics}

The new genus will key to couplet 97 in the key to the genera of the Holarctic Region (Cranston et al. 1989), but no further as the costa is strongly extended and the anal point is hardly extending beyond the posterior margin of tergite IX nor originating from the posterior margin of the tergite. In the key to the Central American Chironomidae (Spies et al. 2009) the genus will key to couplet 122, but no further as the squama is lacking setae and scutum is without a medial tuft of microtrichia.

The genus is difficult to place, but most probably it groups with Pseudosmittia Edwards, further discussion on the group and its Neotropical members in Andersen \& Mendes (2007).

\section{Jururumberus arapuca n. sp. (Figures 1-6)}

Type material: Holotype male: BRAZIL, São Paulo State, Salesópolis, Estação Biológica Boracéia, 10.xii.2001, H.F. Mendes et al. leg. (MZUSP). Paratypes: 1 male, same as holotype (MZUSP); 1 male, same as holotype except 12.xii.2001, C.G. Froehlich et al. leg. (ZMBN).

Etymology: From Tupy ara and puka meaning respectively light and trap due to the method the type material was sampled. The name is to be regarded as a noun in apposition.

Diagnostic characters: The species is larger than J. uatuma $\mathrm{n}$. sp., the wing length is $>0.81 \mathrm{~mm}$ compared to $0.67 \mathrm{~mm}$ in J. uatuma n. sp. The posterior lobe of inferior volsella is broadly rounded, while it is nearly parallel-sided in J. uatuma n. sp. and the crista dorsalis is long and low, while it is triangular and placed subapically in J. uatuma n. sp. 


\subsection{Description}

Male $(\mathrm{n}=2-3)$. Total length 1.33-1.41 mm. Wing length 817-866 $\mu \mathrm{m}$. Total length / wing length 1.59-1.71. Wing length / length of profemur 2.94-3.23.

Coloration. Head, pedicel, thorax and abdominal segments V-VIII dark brown; legs and antennal flagellum lighter brown; abdominal segments I-IV pale brown; wings translucent.

Head (Figure 1). Antennae with 12 flagellomeres; AR 0.28-0.30; ultimate flagellomere (Figure 2) 65-67 $\mu \mathrm{m}$ long. Temporal setae 7-8 including 4 inner verticals, 2-3 outer verticals, and 1-2 postorbital. Clypeus with 5-6 setae. Tentorium, stipes, and cibarial pump as in Figure 3. Tentorium 80-87 $\mu \mathrm{m}$ long; $11-13 \mu \mathrm{m}$ wide. Stipes $52-63 \mu \mathrm{m}$ long. Palp segment lengths / widths (in $\mu \mathrm{m})$ : 6-8 / 8-11; 12-14 / 18-19; 25-32 / 19-22; 23-28 / 12-14; 33-37 / 7-8. Third palpomere with 5-7 sensilla clavata in subapical sensillum coeloconicum, 12-14 $\mu \mathrm{m}$ long.

Thorax. Antepronotum with 2 setae. Dorsocentrals 7-8; prealars 2-3. Scutellum with 4 setae.

Wing (Figure 4). VR 1.41-1.55. Costal extension 158-168 $\mu \mathrm{m}$ long. Brachiolum with 1 seta, remaining veins and cells bare. Squama bare.

Legs. Spur of fore tibia 25-26 $\mu \mathrm{m}$ long; spurs of mid tibia 14-15 $\mu \mathrm{m}$ and 12-14 $\mu \mathrm{m}$ long; spurs of hind tibia $38-40 \mu \mathrm{m}$ and $15-17 \mu \mathrm{m}$ long. Width at apex of fore tibia $18-20 \mu \mathrm{m}$; of mid tibia 17-21 $\mu \mathrm{m}$; of hind tibia 28-33 $\mu \mathrm{m}$. Comb with 11-12 setae; longest 32-36 $\mu \mathrm{m}$ long; shortest 19-21 $\mu \mathrm{m}$ long. Lengths and proportions of legs as in Table 1.

Abdomen. Strong setae on tergites I-VIII as: 0, 4-5, 6-8, 6-8, 7-11, 7-12, 6-10, 7-9. Strong setae on sternites I-VIII as: 0, 0, 0-1, 1-2, 2-6, 3-6, 7-9.

Hypopygium (Figures 12-13). Anal point covered with microtrichia; $15-22 \mu \mathrm{m}$ long; 4-6 $\mu \mathrm{m}$ wide at base. Tergite IX with 6-8 setae; laterosternite IX with 2 setae. Transverse sternapodeme 50-53 $\mu \mathrm{m}$ long. Phallapodeme 48-50 $\mu \mathrm{m}$ long. Virga with 2 spines, longest 10-11 $\mu \mathrm{m}$ long. Gonocoxite 131-137 $\mu \mathrm{m}$ long. Inferior volsella with 7-8 $\mu \mathrm{m}$ long, 10-11 $\mu \mathrm{m}$ wide, broadly rounded lobe projecting caudad. Gonostylus 55-61 $\mu \mathrm{m}$ long, with long, low crista dorsalis, about $30 \mu \mathrm{m}$ long, $3 \mu \mathrm{m}$ high; megaseta $8-11 \mu \mathrm{m}$ long. HR 2.25-2.38. HV 2.32-2.41.

\subsection{Distribution and habitat}

The type material was collected in light traps during an expedition to the Biological Station of Boracéia, Salesópolis municipality, São
Paulo State, in the Mata Atlântica forest. This nature reserve was created in 1954 and comprises an area of 96 hectares $110 \mathrm{~km}$ east of São Paulo city. It is composed of both primary and secondary forests under the protection of the Museu de Zoologia da Universidade de São Paulo (MZUSP: http://www.mz.usp.br/portugues/dci/estacao_ biologica_boraceia/estacao_biologica_boraceia.html).

\section{Jururumberus uatuma n. sp. (Figures 7-13)}

Type material: Holotype male: BRAZIL, Amazonas State: Reserva Biológica Uatumã, Waterfall camp, 31.i.-02.ii.2008, light trap, N. Hamada et al. leg. (INPA).

Etymology: The species is named after the type locality. The name is to be regarded as a noun in apposition.

Diagnostic characters: See diagnostic characters for J. arapuca n. sp.

\subsection{Description}

Male $(\mathrm{n}=1)$. Total length $1.28 \mathrm{~mm}$. Wing length $670 \mu \mathrm{m}$. Total length / wing length 1.90. Wing length / length of profemur 2.73 .

Coloration. Head, pedicel and abdominal segments V-VIII brown; thorax brown with slightly darker brown vitae, median anepisternum, preepisternum, scutellum and postnotum; legs and antennal flagellum lighter brown; abdominal segments I-IV pale brown; wings translucent.

Head. Antennae with 12 flagellomeres; AR 0.27; ultimate flagellomere $97 \mu \mathrm{m}$ long. Temporal setae 8 including 5 inner verticals, 2 outer verticals, and 1 postorbital. Clypeus with 6 setae. Tentorium $82 \mu \mathrm{m}$ long, $14 \mu \mathrm{m}$ wide. Stipes $55 \mu \mathrm{m}$ long. Palp segment lengths / widths (in $\mu \mathrm{m}$ ): 6 / 8, 18 / 14, 30 / 22, 28 / 13, 26 / 8. Third palpomere with about 6 sensilla clavata in subapical sensillum coeloconicum, about $11 \mu \mathrm{m}$ long.

Thorax (Figure 8). Antepronotum with 2 setae. Dorsocentrals 6; prealars 3. Scutellum with 4 setae.

Wing (Figure 7). VR 1.47. Costal extension $135 \mu \mathrm{m}$ long. Brachiolum with 1 seta, remaining veins and cells bare. Squama bare.

Legs (Figures 9-11). Spur of fore tibia $19 \mu \mathrm{m}$ long, spurs of mid tibia $12 \mu \mathrm{m}$ and $11 \mu \mathrm{m}$ long, spurs of hind tibia $36 \mu \mathrm{m}$ and $14 \mu \mathrm{m}$ long. Width at apex of fore tibia $18 \mu \mathrm{m}$, of mid tibia $21 \mu \mathrm{m}$, of hind tibia $26 \mu \mathrm{m}$. Comb with 9 setae, longest $28 \mu \mathrm{m}$ long; shortest $18 \mu \mathrm{m}$ long. Lengths and proportions of legs as in Table 2.

Abdomen. Strong setae on tergites I-VIII as: 0, 0, 0, 1, 5, 7, 4, 5 . Strong setae on sternites I-VIII as: 0, 0, 0, 0, 1, 2, 3, 7.

Table 1. Lengths (in $\mu \mathrm{m})$ and proportions of legs of Jururumberus arapuca $\mathrm{n}$. gen., n. sp., male $(\mathrm{n}=2-3)$.

\begin{tabular}{|c|c|c|c|c|c|c|}
\hline & fe & ti & $\mathrm{ta}_{1}$ & $\mathrm{ta}_{2}$ & $\mathrm{ta}_{3}$ & $\mathbf{t a}_{4}$ \\
\hline $\mathrm{p}_{1}$ & $292-296$ & $328-336$ & $200-204$ & $84-88$ & $56-60$ & $36-40$ \\
\hline $\mathrm{p}_{2}$ & $356-360$ & $332-340$ & $148-160$ & $60-68$ & $44-48$ & $31-33$ \\
\hline $\mathrm{p}_{3}$ & $320-324$ & $332-340$ & $192-208$ & $80-84$ & $96-100$ & $35-37$ \\
\hline & $\mathrm{ta}_{5}$ & LR & \multicolumn{2}{|c|}{ BV } & SV & BR \\
\hline $\mathrm{p}_{1}$ & $29-34$ & $0.61-0.62$ & \multicolumn{2}{|c|}{$3.80-4.02$} & $3.06-3.10$ & $2.66-3.12$ \\
\hline $\mathrm{p}_{2}$ & $27-29$ & $0.44-0.47$ & \multicolumn{2}{|c|}{$4.24-5.04$} & $4.35-4.70$ & $2.44-3.44$ \\
\hline $\mathrm{p}_{3}$ & $31-33$ & $0.57-0.61$ & \multicolumn{2}{|c|}{$3.46-3.47$} & $3.19-3.40$ & $3.20-3.40$ \\
\hline
\end{tabular}

Table 2. Lengths (in $\mu \mathrm{m}$ ) and proportions of legs of Jururumberus uatuma n. gen., n. sp., male $(\mathrm{n}=1)$.

\begin{tabular}{|c|c|c|c|c|c|c|c|c|c|c|c|}
\hline & fe & ti & $\mathrm{ta}_{1}$ & $\mathrm{ta}_{2}$ & $\mathrm{ta}_{3}$ & $\mathrm{ta}_{4}$ & $\mathrm{ta}_{5}$ & $\mathbf{L R}$ & BV & SV & BR \\
\hline $\mathrm{p}_{1}$ & 240 & 276 & 160 & 56 & 44 & 28 & 24 & 0.58 & 4.45 & 3.23 & 2.6 \\
\hline $\mathrm{p}_{2}$ & 296 & 280 & 120 & 48 & 40 & 24 & 20 & 0.43 & 5.27 & 4.80 & 2.2 \\
\hline $\mathrm{p}_{3}$ & 272 & 284 & - & - & - & - & - & - & - & - & - \\
\hline
\end{tabular}



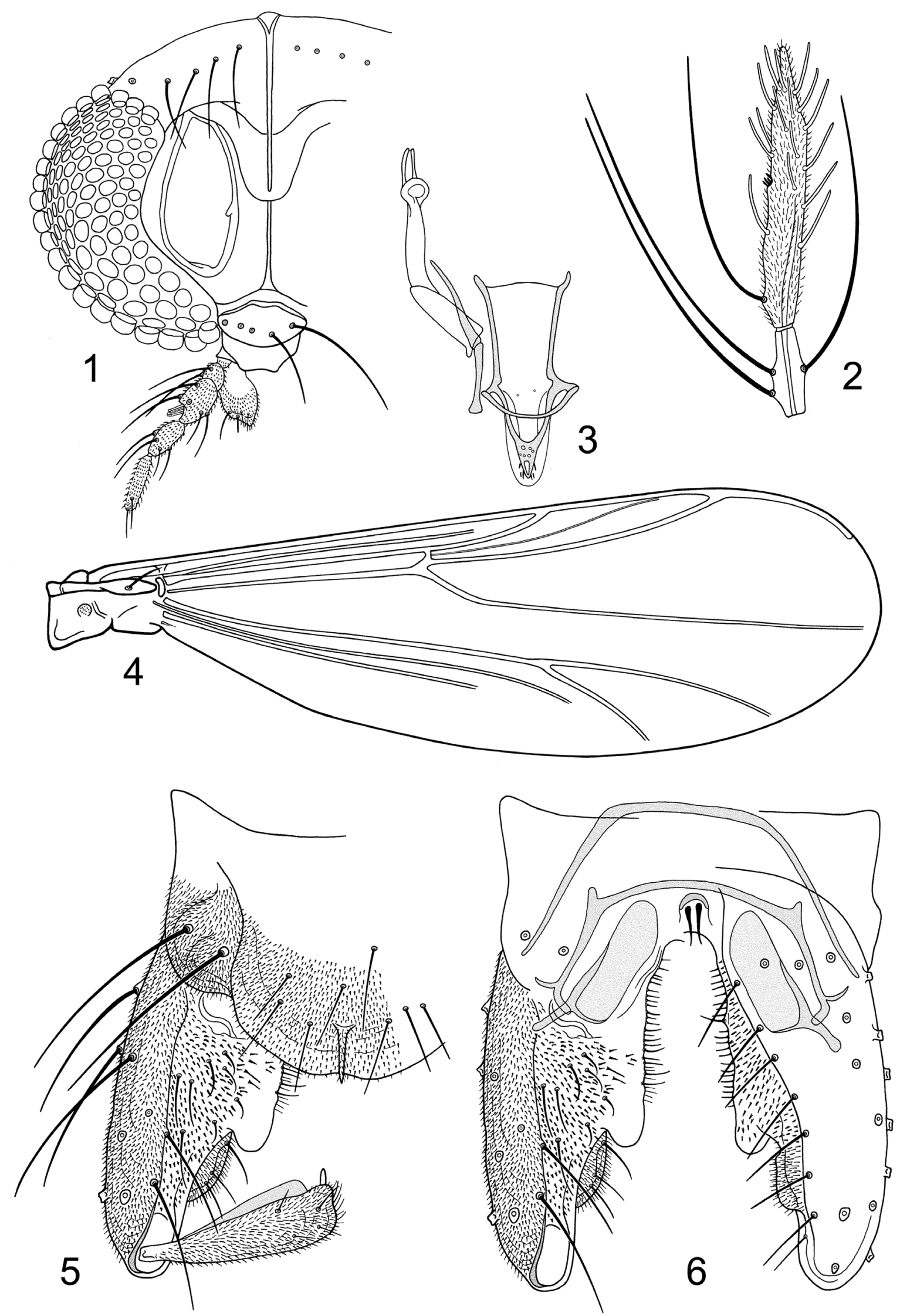

Figures 1-6. Jururumberus arapuca n. gen.; n. sp., male. 1) Head. 2) Ultimate flagellomeres of antenna. 3) Tentorium, stipes and cibarial pump. 4) Wing. 5) Hypopygium, dorsal view. 6) Hypopygium with anal point and tergite IX removed, dorsal aspect to the left and ventral aspect to the right. 

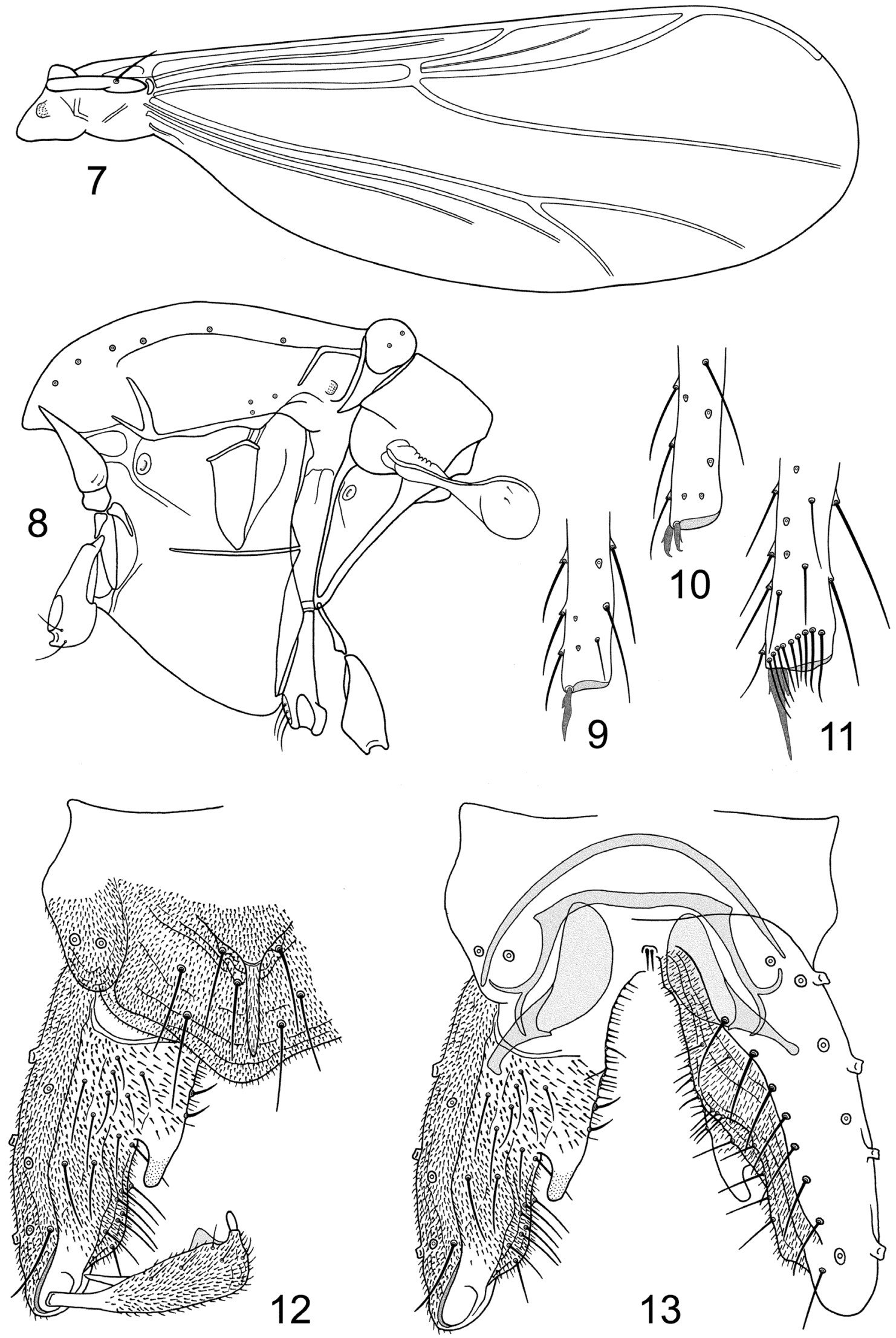

Figures 7-13. Jururumberus uatuma n. gen.; n. sp., male. 7) Wing. 8) Thorax. 9) Apex of fore tibia. 10) Apex of mid tibia. 11) Apex of hind tibia. 12) Hypopygium, dorsal view. 13) Hypopygium with anal point and tergite IX removed, dorsal aspect to the left and ventral aspect to the right. 
Hypopygium (Figures 12-13). Anal point covered with microtrichia, $22 \mu \mathrm{m}$ long, $5 \mu \mathrm{m}$ wide at base. Tergite IX with 7 setae including 3 sitting at base of anal point; laterosternite IX with 2 setae. Transverse sternapodeme $33 \mu \mathrm{m}$ long. Phallapodeme $46 \mu \mathrm{m}$ long. Virga of 2 weak spines, longest $5 \mu \mathrm{m}$ long. Gonocoxite $104 \mu \mathrm{m}$ long. Inferior volsella with $10 \mu \mathrm{m}$ long, $6 \mu \mathrm{m}$ wide, parallel-sided lobe projecting caudad. Gonostylus $43 \mu \mathrm{m}$ long, with triangular subapical crista dorsalis, $7 \mu \mathrm{m}$ wide, $5 \mu \mathrm{m}$ high; megaseta $7 \mu \mathrm{m}$ long. HR 2.42. HV 2.98.

\subsection{Distribution and habitat}

This species is known only from the holotype collected close to a waterfall in a federal nature reserve located in Presidente Figueiredo (REBIO Uatumã), Amazonas State, in the Amazon forest. The reserve was created in 1990 and comprises and area of 9500 hectares and has on its preservation list the Amazonian manatee, Trichechus inunguis (Natterer, 1883) and the freshwater sponge Anheteromeyenia ornata (Bonetto et Ezcurra de Drago,1970). This freshwater sponge is protected only in this nature reserve and deserves special attention.

\section{Acknowledgements}

We are indebted to Dr. Claudio Gilberto Froehlich, FFCLRP/ USP for arranging the expedition to the type locality of Jururumberus arapuca gen. n., n. sp. and Dr. Neusa Hamada, INPA, for the material of J. uatuma n. sp. Gladys Ramirez made the slide preparations. The study was partially funded by FAPESP (11/50162-1), partially by the University Museum of Bergen.

\section{References}

ANDERSEN, T. \& MENDES, H.F. 2007. Five enigmatic new orthoclad genera from Brazil (Diptera: Chironomidae, Orthocladiinae). In Contributions to the Systematics and Ecology of Aquatic Diptera - A tribute to Ole A. Sæther. (T. Andersen, ed.). The Caddis Press, Columbus, p.17-52.

CRANSTON, P.S., OLIVER, D.R. \& SÆTHER, O.A. 1989. The adult males of Orthocladiinae (Diptera: Chironomidae) of the Holarctic region. Keys and diagnoses. In Chironomidae of the Holarctic region. Keys and diagnoses. Part 3. Adult males (T. Wiederholm, ed.). Ent. scand., Suppl. 34:165-352.

MENDES, H.F. \& PINHO, L.C. 2011. Brazilian chironomid home page. http://sites.google.com/site/brazilianchironomids/ (último acesso em 12/06/2013)

MENDES, H. F., ANDERSEN, T. \& PINHO, L.C. 2007. Taxonomic research on Brazilian Orthocladiinae (Diptera: Chironomidae) during the last decade. Entomol. Mex. 6:1173-1177.

MENDES, H.F., ANDERSEN, T. \& SÆTHER, O.A. 2004. New species of Ichthyocladius Fittkau, a member of the Corynoneura-group (Diptera: Chironomidae: Orthocladiinae), with a review of the genus. Stud. Neotrop. Fauna Environ. 39:15-35. http://dx.doi.org/10.1080/0165052 0412331270936

SÆTHER, O.A. 1969. Some Nearctic Podonominae, Diamesinae and Orthocladiinae (Diptera: Chironomidae). Bull. Fish. Res. Board Canada 107:1-154.

SÆTHER, O.A. 1980. Glossary of Chironomid morphology terminology (Diptera: Chironomidae). Ent. Scand., Suppl. 14:1-51.

SPIES, M. \& REISS, F. 1996. Catalog and bibliography of neotropical and Mexican Chironomidae (Insecta, Diptera). Spixiana, Suppl. 22:61-119.

SPIES, M., ANDERSEN, T., EPLER, J.H. \& WATSON JUNIOR, C.N. 2009. Chironomidae (Non-biting midges). In Manual of Central American Diptera (B.V. Brown, A. Borkent, J.M. Cumming, D.M. Wood, N.E. Woodley \& M.A. Zumbado, eds.). NRC Research Press, Ottawa, p.437480 . 